\title{
Pengaruh Kemasaman, Suhu, dan Cahaya terhadap Golovinomyces sordidus Penyebab Penyakit Embun Tepung pada Plantago major
}

\section{Acidity, Temperature and Light Effects on Golovinomyces sordidus, Plantago major Powdery Mildew Causal Agent}

\author{
Dini Florina, Dyah Manohara, Dono Wahyuno* \\ Balai Penelitian Tanaman Rempah dan Obat, Bogor 16111
}

\begin{abstract}
ABSTRAK
Ki-urat (Plantago major) merupakan herba yang digunakan sebagai obat. Gejala embun tepung dijumpai pada tanaman ki-urat dan di Indonesia cendawan penyebabnya belum diketahui. Penelitian ini bertujuan mengidentifikasi dan mengetahui pengaruh kemasaman, suhu dan cahaya terhadap cendawan penyebab embun tepung. Identifikasi didasarkan pada karakteristik morfologi. Proses infeksi diamati dengan cara pewarnaan daun yang telah diinokulasi di bawah mikroskop 24, 48, dan 72 jam setelah inokulasi. Pengaruh kemasaman terhadap perkecambahan konidium dan panjang hifa dilakukan dengan membuat suspensi konidium dalam larutan dengan kemasaman 3-9, diinkubasi selama 24 jam pada suhu $25^{\circ} \mathrm{C}$ dan dihindarkan dari cahaya. Pengaruh suhu terhadap perkecambahan konidium dan panjang hifa diuji dengan meletakkan suspensi konidium pada gelas preparat, diinkubasi pada kisaran suhu $20-35^{\circ} \mathrm{C}$ selama 24 jam dalam gelap. Pengaruh cahaya terhadap perkecambahan konidium dan panjang hifa diuji dengan inkubasi suspensi konidium pada kondisi gelap atau terang (400 Lux) selama 24 jam. Pengaruh lama inkubasi di tempat teduh diuji dengan meletakkan ki-urat yang telah diinokulasi di tempat teduh selama $0,24,48,72,96,120$, dan 144 jam setelah inokulasi. Penyebab gejala embun tepung pada tanaman ki-urat diidentifikasi sebagai Golovinomyces sordidus (syn. Erysiphe sordida) dengan bentuk tidak sempurna berupa Oidium. Koloni embun terbentuk pada hari ke-6 sampai ke-8 setelah inokulasi. Konidium berkecambah dan menginfeksi daun dengan menembus kutikula, kurang dari 24 jam setelah inokulasi. Kemasaman antara 4-7, suhu antara $25-30{ }^{\circ} \mathrm{C}$ dan dihindarkan dari cahaya merupakan konidisi optimum untuk berkecambah dan menginfeksi tanaman.
\end{abstract}

Kata kunci: Golovinomyces sordidus, Ki-urat, Oidium, suspensi konidium

\begin{abstract}
Unidentified powdery mildew was found on leaves of a medicinal plant, Plantago major in Indonesia. The present studies were aimed to identify the causal fungal species of powdery mildew of P. major and study the effect of acidity, temperature and light on the causal fungus. Identification was conducted by observing morphological characteristics of the fungus scraped from diseased leaves under light microscope. The infection process was observed by staining the inoculated leaves followed observation under light microscope. Conidia were suspended in various $\mathrm{pH}$ solutions to examine effect of $\mathrm{pH}$ on conidial germination and hyphal length. For testing effects of temperature on conidial germination and hyphal length, conidial suspensions were dropped onto glass slides then incubated in temperature ranges from $20-35{ }^{\circ} \mathrm{C}$, the germinating conidia and length of the existing hypha were counted and measured \footnotetext{
Pelajar No. 3, Bogor 16111

Telp.0251-8321879,Faks.0251-8327010,Surel: dwahyuno@yahoo.ca; balittro@litbang.deptan.go.id
}

*Alamat penulis korespondensi: Balai Penelitian Tanaman Rempah dan Obat, Badan Litbang Pertanian. Jalan Tentara
\end{abstract}


24 hours later. With the same method as above the glass slides were incubated in $25^{\circ} \mathrm{C}$ either in the dark or exposed under illuminated white light tube (400 Lux) for study effect of light on conidial germination. The causal fungus was identified as Golovinomyces sordidus (syn. Erysiphe sordida) with its anamorph state as Oidium. The germinating conidia penetrate directly into leaf tissue within 24 hours. The optimal conditions for the conidia to germinate are $\mathrm{pH}$ between 4 and 7 , temperature between $25^{\circ} \mathrm{C}$ and $30^{\circ} \mathrm{C}$, and dark condition.

Key words: Golovinomyces sordidus, Ki-urat, Oidium, suspension of conidium

\section{PENDAHULUAN}

Ki-urat atau daun sendokan (Plantago major) merupakan tanaman herba yang kadang dianggap sebagai kelompok gulma. Biji dan daun tanaman ki-urat banyak digunakan sebagai bahan berbagai obat tradisional (Samuelsen 2000). Daun tanaman ki-urat mengandung senyawa fenol, flavonoid dan antioksidan yang tinggi (Kobeasy et al. 2011). Tanaman Ki-urat juga berpotensi sebagai fitoremedia tanah yang tercemar Plumbum (Kosobrukhov et al. 2004) atau air yang tercemar insektisida dengan bahan aktif cyanophos (Romeh 2014). Ki-urat merupakan tanaman herba tahunan yang berbentuk roset dan tumbuh di padang rumput, lahan yang basah, tepi pantai hingga di dataran tinggi $2700 \mathrm{~m}$ dpl (Pangemanan 1999). Di Indonesia, tanaman ki-urat belum dibudidayakan secara intensif, sehingga keperluan akan tanaman ini diambil dari alam.

Gejala penyakit embun tepung banyak ditemukan pada daun tanaman Plantago yang terdapat di Instalasi Penelitian Cimanggu, Balittro, Bogor. Penyakit ini banyak ditemukan selama musim kemarau dan sebaliknya pada saat musim hujan.

Gejala embun tepung berwarna putih umumnya ditemukan di permukaan atas daun (epiphyllous). Pada serangan yang lebih lanjut embun tepung juga terbentuk dikedua permukaan daun (amphigenous), juga tangkai daun (petiole). Pada kondisi tersebut kolonikoloni embun tepung tumbuh dan menyatu, menyebabkan permukaan daun tertutup oleh kumpulan koloni yang berwarna putih, terbentuk nekrosis, daun gugur lebih awal, dan tanaman menjadi lemah. Koloni embun tepung banyak dijumpai pada tanaman ki-urat yang ternaungi dibandingkan dengan tanaman yang tidak ternaungi. Kehilangan hasil akibat penyakit embun tepung pada tanaman kiurat belum diketahui, tetapi serangan embun tepung menjadi penting karena selain bijinya, tanaman ki-urat juga dipanen daunnya. Di daerah yang lembap dan bersuhu rendah di Lithuania, kehilangan hasil gandum akibat serangan dengan gejala embun tepung yang disebabkan oleh Erysiphe graminis dapat mencapai 50\% (Ruzgas et al. 2002), dan di India, embun tepung yang disebabkan oleh Erysiphe pisi dapat menyebabkan kehilangan hasil hingga 50\% pada kacang kapri (Pisum sativum) (Nisar et al. 2006).

Di Indonesia, cendawan penyebab embun tepung pada tanaman ki-urat belum pernah dilaporkan (Kobayashi et al. 1993). Tujuan penelitian ini ialah mengidentifikasi patogen penyebab penyakit embun tepung dan mengamati pengaruh kemasaman, suhu dan cahaya terhadap perkecambahan konidium cendawan penyebabnya.

\section{BAHAN DAN METODE}

\section{Identifikasi}

Identifikasi didasarkan pada pengamatan dan pengukuran struktur karakteristik morfologi cendawan yang ditemukan. Cendawan diambil dari permukaan daun yang menunjukkan gejala embun tepung, dimasukkan ke dalam larutan Shear's di kaca preparat, selanjutnya diamati menggunakan mikroskop cahaya (Crous et al. 2009). Data morfologi yang diperoleh dibandingkan dengan deskripsi yang ada. Bahan tanaman yang diamati diawetkan sebagai herbarium dan disimpan di laboratorium Hama dan Penyakit, Balittro, Bogor (HBAL-Bal 301). 
Penyediaan inokulum embun tepung untuk uji pengaruh lingkungan terhadap perkecambahan dan infeksi dilakukan dengan cara membuat suspensi konidium yang berasal dari satu koloni. Konidium dikumpulkan dengan cara merendam daun yang mengandung koloni embun tepung ke dalam air steril kemudian dikocok selama 2-3 menit dengan alat pengocok (Shomari dan Kennedy 1999). Suspensi konidium yang diperoleh diinokulasikan menggunakan kuas pada daun ki-urat yang masih sehat (Bardin et al. 2007). Tanaman yang telah diinokulasi diinkubasi di tempat teduh di rumah kaca dengan kisaran suhu antara $24-30{ }^{\circ} \mathrm{C}$. Tanaman ki-urat yang telah terserang tersebut digunakan sebagai sumber inokulum pada uji selanjutnya.

\section{Uji Patogenisitas dan Proses Infeksi}

Uji patogenisitas dilakukan menggunakan tanaman ki-urat yang diperbanyak dari benih. Massa konidium embun tepung diambil dari tanaman ki-urat yang diinokulasi secara buatan. Inokulasi dilakukan dengan mengoleskan suspensi konidium dengan konsentrasi $1.8 \times 10^{6}$ konidium $\mathrm{mL}^{-1}$ pada permukaan daun yang sehat, kemudian tanaman diinkubasi di rumah kaca. Pengamatan gejala penyakit yang timbul dilakukan setiap hari. Kontrol adalah tanaman yang diinokulasi dengan air dengan cara yang sama seperti di atas.

Perkecambahan konidium dan proses infeksi pada tanaman yang telah diinokulasi diamati pada 24, 36, dan 72 jam setelah inokulasi. Potongan daun $(1 \mathrm{~cm} \times 1 \mathrm{~cm})$ dimasukkan ke dalam larutan pewarna laktofenol biru metilen (laktophenol cotton blue) dan dipanaskan selama \pm 1 menit, kemudian dibiarkan selama 48 jam (Liberato et al. 2005). Potongan daun kemudian direndam dalam larutan kloral hidrat (2:1) untuk mengurangi pewarnaan yang berlebihan, selanjutnya dimasukkan ke dalam larutan gliserol campur air (1:1) pada kaca preparat, dan diamati menggunakan mikroskop cahaya.

\section{Kemasaman Medium}

Uji pengaruh kemasaman air terhadap perkecambahan konidium, dilakukan dengan cara merendam daun yang membawa koloni embun tepung ke dalam air dengan kemasaman 4, 5, 6, 7, 8, dan 9 selama 60 detik. Kemasaman air diatur menggunakan $\mathrm{HCl}$ atau $\mathrm{NaOH}$ 0.1 M (Schrandt dan Davis 1994). Suspensi konidium dibuat dengan mencampur konidium pada larutan yang telah diatur kemasamannya dengan konsentrasi berkisar antara 3.5-6.2 × $10^{4}$ konidium $\mathrm{mL}^{-1}$ diteteskan pada kaca preparat (Bahadur et al. 2008), kemudian dikeringanginkan dan diinkubasi selama 24 jam di dalam kotak yang telah diberi kertas yang sudah dibasahi. Konidium yang berkecambah dan panjang hifa yang terbentuk pada masing-masing perlakuan dihitung dan diukur menggunakan mikroskop.

\section{Suhu}

Uji pengaruh suhu terhadap perkecambahan dan pertumbuhan hifa dilakukan dengan meneteskan suspensi konidium pada kaca preparat, diletakkan dalam kotak plastik yang alasnya telah diberi kertas saring basah. Kotak plastik yang berisi suspensi konidium diinkubasi pada kisaran suhu 20, 25, 30, dan $35{ }^{\circ} \mathrm{C}$, selama 24 jam dalam keadaan gelap. Larutan laktofenol diteteskan pada permukaan kaca preparat untuk menghentikan proses perkecambahan, kemudian diamati menggunakan mikroskop. Pengamatan, terhadap 100 konidium yang berkecambah dan panjang hifa yang terbentuk, dihitung dan diukur menggunakan mikroskop dengan 3 kali ulangan untuk setiap perlakuan.

\section{Cahaya}

Uji pengaruh cahaya terhadap perkecambahan konidium dilakukan dengan meneteskan suspensi konidium pada permukaan kaca preparat, kemudian diletakkan ke dalam cawan petri dengan kertas saring basah di dalamnya. Cawan petri berisi kaca preparat diletakkan di bawah cahaya selama 24 jam pada suhu $\pm 25^{\circ} \mathrm{C}$. Sebagai sumber cahaya digunakan lampu TL 20 W (400 Lux; Tokyo Koden, ANA 500) dan kontrol tanpa pencahayaan. Jumlah konidium yang berkecambah dan hifa yang terbentuk dihitung dan diukur, seperti perlakuan suhu. 
Pengaruh Lama Inkubasi di Tempat Teduh terhadap Insidensi Penyakit

Penelitian dilakukan di kebun menggunakan tanaman berumur \pm 4 bulan yang dipelihara pada medium tanah dicampur pupuk kandang (2:1) dan dihindarkan tertular oleh konidium dari luar. Inokulasi dilakukan pagi hari dengan cara menyemprotkan suspensi konidium (konsentrasi $8 \times 10^{4}$ konidium $\mathrm{mL}^{-1}$ ) ke permukaan tanaman. Tanaman diletakkan di lapangan dengan perlakuan $0,24,48,72$, 96, 120, dan 144 jam setelah diinokulasi. Tanaman diletakkan di bawah naungan dengan atap plastik transparan dan diatur sedemikian rupa sehingga tanaman akan terpapar cahaya matahari antara pukul 08.00-13.30 WIB. Jarak antar pot ialah $\pm 15 \mathrm{~cm}$ sehingga tidak ada saling ternaungi antar kanopi. Jarak antara atap dan daun tanaman berkisar $\pm 50 \mathrm{~cm}$ dengan intensitas cahaya pada pukul 12.00 WIB sebesar \pm 23000 Lux, dengan kisaran suhu $23-31^{\circ} \mathrm{C}$. Sebagai kontrol, tanaman diinkubasi di rumah kaca dan terhindar dari cahaya langsung. Setiap perlakuan diulang tiga kali. Pengamatan dilakukan terhadap jumlah daun dan tanaman yang terserang, serta jumlah koloni embun tepung yang terbentuk dari tiap perlakuan pada hari ke-10 setelah inokulasi.

\section{HASIL}

\section{Identifikasi}

Morfologi telomorf cendawan tidak ditemukan, yang ada hanya bentuk anamorf Oidium. Konidiofor dengan sel kaki (footcell) tersusun dari tiga sel dengan ukuran tidak sama. Sel pertama biasanya lebih panjang daripada dua sel lainnya. Sel kaki umumnya agak melengkung, kecil di bagian bawah dan lebar di atas, berukuran 25.0-(32.8)-50.0 $\mu \mathrm{m}$ $\times$ 6.3-(10.2)-17.5 $\mu \mathrm{m}$ dan tidak berwarna (hialin). Panjang sel pertama 35.0-(45.2) $-62.5 \mu \mathrm{m} \times 8.8-(12.1)-15.0 \mu \mathrm{m}$ (Gambar 1b). Konidium tidak berornamen, terbentuk pada konidiofor, tersusun seperti rantai, berbentuk lonjong dengan sudut membulat (oblong) sampai silindris (cylindric). Konidium hialin, berukuran 30.0-(34.7)-40.0 $\mu \mathrm{m} \times 11.3$ (14.1)-18.8 $\mu \mathrm{m}$ (Gambar 1c). Berdasarkan pada ciri morfologi ini cendawan pada daun ki-urat ini ialah Golovinomyces sordidus.

\section{Uji Patogenisitas dan Proses Infeksi}

Gejala penyakit embun tepung berupa bintik-bintik berwarna putih dengan diameter 3-5 mm terlihat di permukaan atas daun pada 6-8 hari setelah inokulasi dengan konidium yang terbentuk masih muda dan tidak mudah terlepas. Konidium pada konidiofor menjadi dewasa dan dapat menginfeksi daun sehat pada 11-13 hari setelah inokulasi, ditandai dengan ukuran konidium yang besar dan terlihat tepung berwarna putih berhamburan di udara apabila daun tersentuh.

Pada saat 24 jam setelah inokulasi perkecambahan konidium ialah sebesar $24.3 \%$ dengan konidium yang berkecambah lebih dari satu tabung kurang dari 3\%. Tabung kecambah tumbuh menjadi hifa dengan panjang antara 15 dan $550 \mu \mathrm{m}$ (Gambar 1d). Pada tahap ini belum ditemukan hifa yang tumbuh di dalam jaringan daun. Konidium yang berkecambah 48 jam setelah inokulasi ialah 22\% dengan panjang hifa berkisar antara 17 dan $625 \mu \mathrm{m}$. Beberapa hifa telah membentuk percabangan dan beberapa diantaranya telah menginfeksi daun yang ditandai dengan terlihatnya hifa yang tumbuh di dalam jaringan daun. Infeksi terjadi secara langsung dengan cara menembus kutikula daun tanpa membentuk apresorium dan tidak ditemukan infeksi yang melalui stoma. Bagian hifa yang menginfeksi berasal dari percabangan yang keluar dari tabung kecambah. Konidium yang berkecambah 72 jam setelah inokulasi ialah $25.5 \%$ dengan panjang hifa antara 20 dan $640 \mu \mathrm{m}$. Hifa yang sudah ada di dalam jaringan tanaman membentuk percabangan dan haustorium (Gambar 1e).

\section{Kemasaman}

Konidium dapat berkecambah pada kisaran kemasaman antara 3 dan 9, dengan kemasaman optimum antara 5 dan 6 (Gambar 2a), tetapi rata-rata panjang hifa tidak berbeda nyata pada semua perlakuan kemasaman yang diuji (Gambar 2b). 

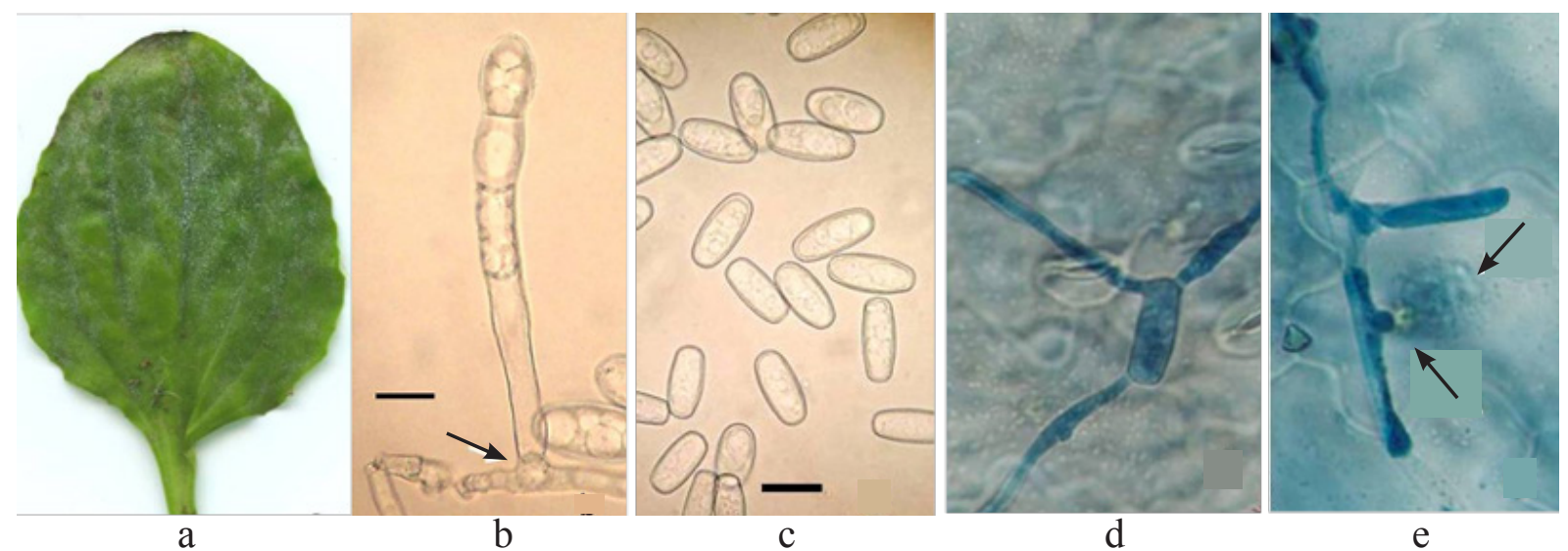

Gambar 1 Tanaman ki-urat terserang Golovinomyces sordidus. a, gejala embun tepung; b, konidiofor dengan sel kaki $(\rightarrow)$; c, konidium; d, konidium berkecambah; dan e, hifa menginfeksi jaringan daun dan membentuk haustorium $(\rightarrow)$. Skala: $1 \mathrm{~b}$ dan $1 \mathrm{c}=20 \mu \mathrm{m}$.

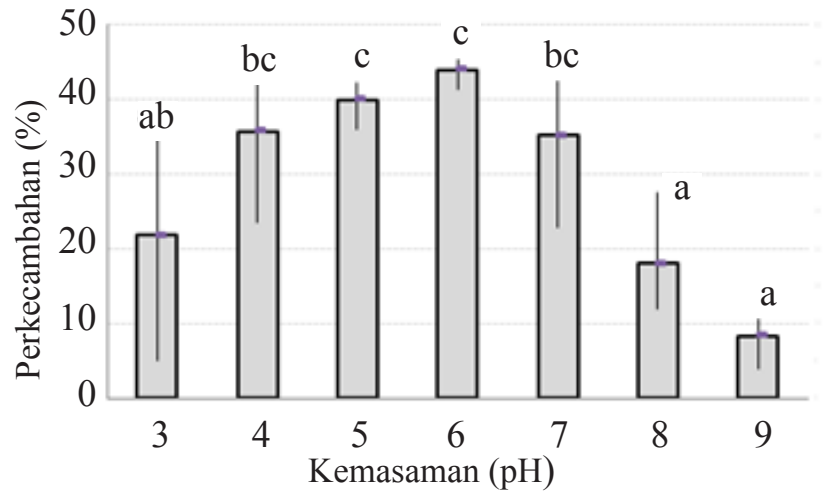

a

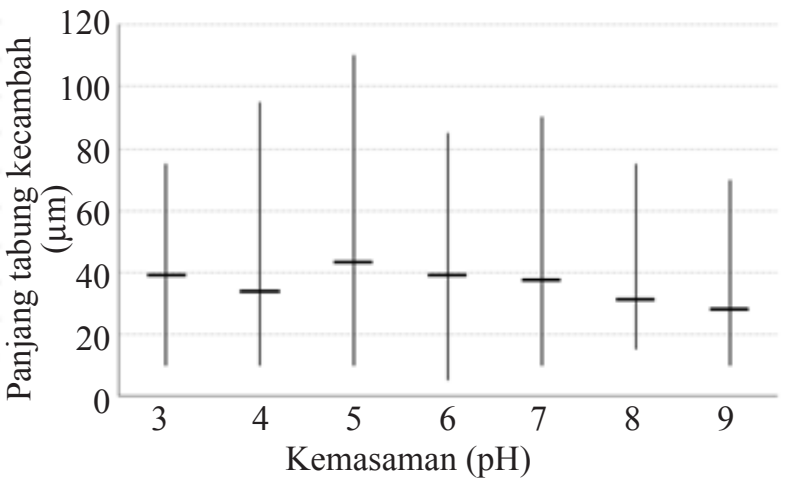

$\mathrm{b}$

Gambar 2 Perkecambahan konidium Golovinomyces sordidus dan panjang tabung kecambahnya pada beberapa kemasaman medium setelah diinkubasi selama 24 jam. a, persentase perkecambahan G. sordidus. Notasi huruf yang sama menunjukkan persentase perkecambahan yang tidak berbeda nyata pada taraf kepercayaan 5\%; dan b, panjang hifa. Garis vertikal menunjukkan kisaran nilai panjang tabung kecambah

\section{Suhu}

Konidium dapat berkecambah pada semua kisaran suhu yang diuji $\left(20-35^{\circ} \mathrm{C}\right)$ dengan persentase perkecambahan yang baik pada kisaran $20-35^{\circ} \mathrm{C}$ (Gambar 3a). Pada konidium yang berkecambah, rata-rata panjang hifa tidak berbeda nyata pada semua perlakuan lainnya (Gambar 3b).

\section{Cahaya}

Cahaya dengan intensitas \pm 400 Lux, menghambat perkecambahan konidium sebesar 30\% dibandingkan dengan yang diinkubasi di tempat gelap. Panjang hifa yang terbentuk pada perlakuan gelap lebih pendek, tetapi panjang hifa yang terbentuk tidak berbeda nyata antara perlakuan inkubasi di tempat gelap dan terang (Gambar 4).

\section{Insidensi Penyakit}

Pada hari ke-10 setelah inokulasi, koloni cendawan terlihat di permukaan atas daun pada perlakuan yang diinkubasi 24-144 jam di tempat teduh, sebelum dipindah ke lapangan berupa bercak-bercak warna putih halus dengan diameter $\pm 3-5 \mathrm{~mm}$. Semua tanaman terserang cendawan embun tepung. Koloni cendawan yang terbentuk pada permukaan bawah daun jumlahnya hanya kurang dari $10 \%$. Koloni embun tepung tidak ditemukan pada daun tanaman yang diberi perlakuan inkubasi ditempat teduh selama 0 jam (Gambar 5). 

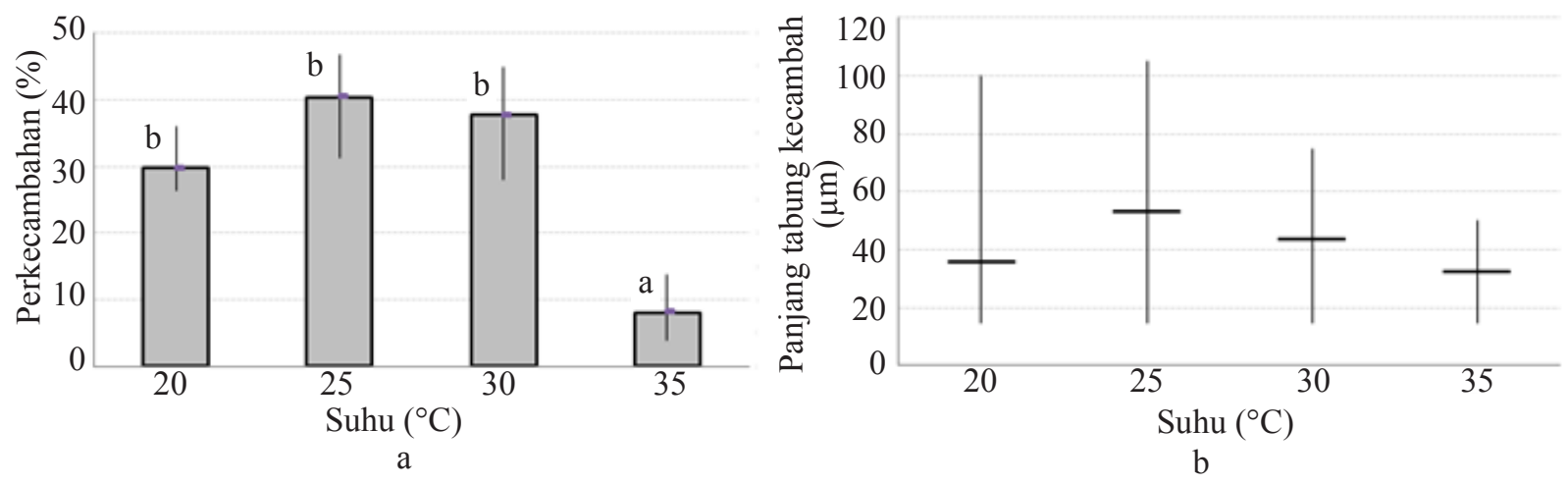

Gambar 3 Perkecambahan konidium Golovinomyces sordidus pada beberapa suhu inkubasi selama 24 jam. a, persentase perkecambahan G. sordidus. Notasi huruf yang sama menunjukkan persentase perkecambahan yang tidak berbeda nyata pada taraf kepercayaan 5\%; dan b, panjang hifa $G$. sordidus. Garis vertikal menunjukkan kisaran nilai panjang tabung kecambah.
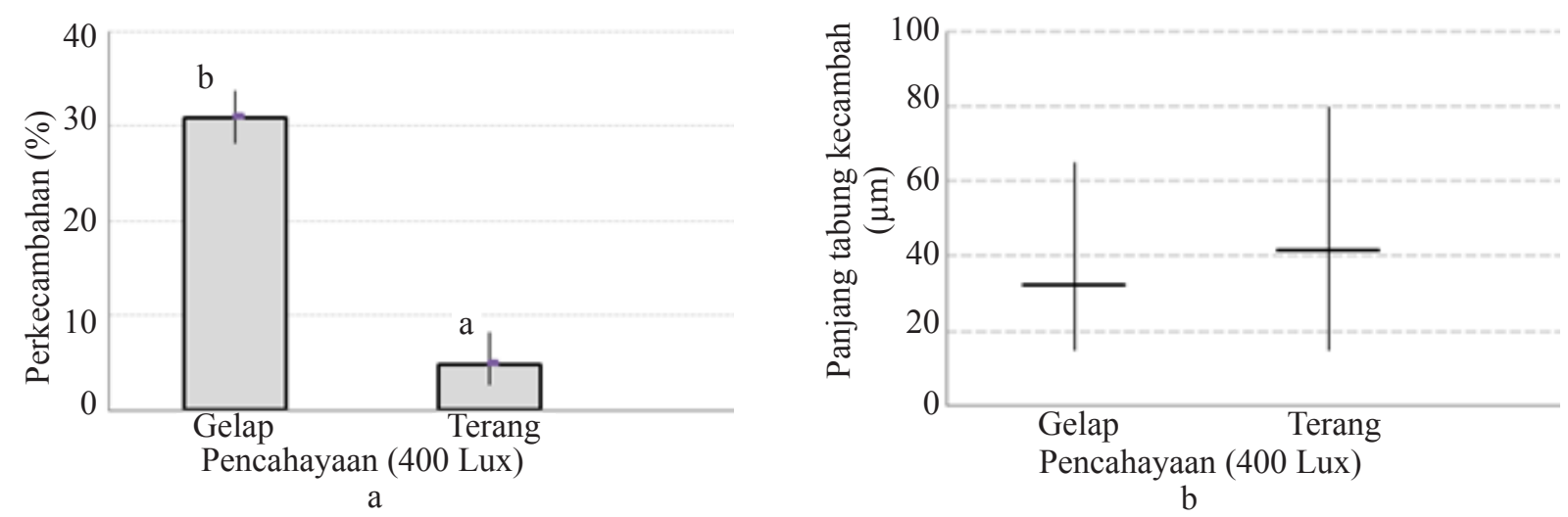

Gambar 4 Perkecambahan konidium Golovinomyces sordidus pada kondisi gelap dan terang setelah diinkubasi selama 24 jam. a, persentase perkecambahan G. sordidus. Notasi huruf yang sama menunjukkan persentase perkecambahan yang tidak berbeda nyata pada taraf kepercayaan $5 \%$; dan b, panjang hifa G. sordidus. Garis vertikal menunjukkan kisaran nilai panjang tabung kecambah.

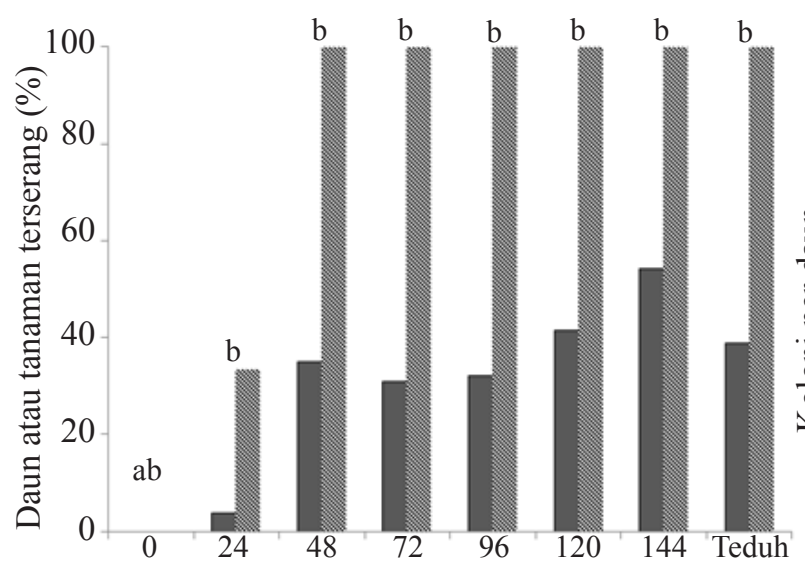

Inkubasi di tempat teduh setelah diinokulasi (jam)

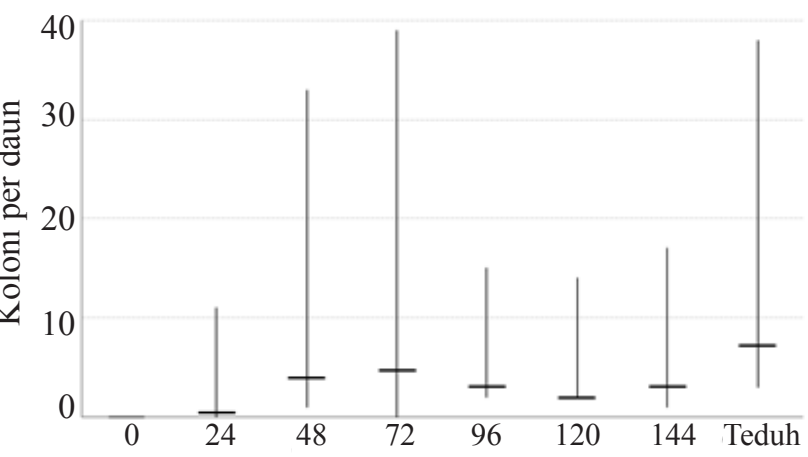

Inkubasi di tempat teduh setelah diinokulasi (jam) b

Gambar 5 Daun dan tanaman ki-urat yang terserang penyakit embung tepung dan jumlah koloni masa konidium pada daunnya setelah diinokulasi di tempat teduh selama 0-144 jam. $\boldsymbol{\square}$, daun ki-urat; , tanaman ki-urat. Notasi huruf yang sama menunjukkan persentasi daun yang tidak berbeda nyata pada taraf kepercayaan 5\%. Garis vertikal menunjukkan kisaran nilai jumlah koloni cendawan pada daun dan garis horizontal ialah rata-rata jumlah koloni. 


\section{PEMBAHASAN}

Ada tiga spesies cendawan diketahui menimbulkan gejala embun tepung pada Plantago spp. Di Amerika, G. sordidus (syn. Erysiphe sordida) dan Sphaerotheca macularis menyebabkan gejala embun tepung pada Plantago spp. (Farr et al. 1989; Dugan dan Glawe 2007). Cendawan G. sordidus ditemukan pada $P$. tomentosa di Argentina (Delhey et al. 2003); Golovinomyces sp. pada P. australis di Brasil (Dallagnol et al. 2012). Di Eropa, G. sordidus (syn E. sordida) pada $P$. major dan Sphaerotheca plantaginis pada $P$. eriopoda, P. lanceolata, P. major (Braun 1987). Selain Golovinomyces dan Sphaerotheca, gejala embun tepung pada Plantago spp. juga disebabkan oleh cendawan Leveillula taurica (Braun 1987).

Cendawan Golovinomyces, Sphaerotheca, dan Leveillula dapat dibedakan berdasarkan karakter bentuk dan jumlah sel pada sel kaki, serta bentuk konidium dari stadium anamorfnya, yaitu Oidium. Golovinomyces mempunyai sel kaki berbentuk silindris dan melengkung, dengan konidium berbentuk lonjong (oblong). Sel kaki S. plantaginis berbentuk silindris dan tegak, konidiumnya berbentuk elips (ellipsoid) sampai membulat telur (ovoid); sedang L. taurica di atas sel kakinya hanya menghasilkan satu konidium berbentuk lanset, yaitu lebar di bagian dasar meruncing di ujung (lanceolate) (Braun 1987).

Berdasarkan karakter bentuk dan jumlah sel pada sel kaki, serta konidium yang umumnya berbentuk lonjong maka cendawan penyebab embun tepung pada tanaman ki-urat diidentifikasi sebagai Golovinomyces sordidus (Delhey et al. 2003) yang sebelumnya dikenal sebagai Erysiphe sordida (Braun 1987).

Penelitian ini merupakan laporan pertama yang menyatakan keberadaan G. sordidus pada tanaman Plantago di Indonesia. Cendawan $G$. sordidus mempunyai sebaran geografi yang luas meliputi Amerika, Asia, dan Eropa. Sebaran inangnya sangat terbatas yaitu hanya pada tanaman Plantago spp. dan tidak menyerang tanaman lainnya (Braun 1987).
Fase perkecambahan konidium merupakan saat yang peka bagi cendawan terhadap perubahan lingkungan dibandingkan dengan pertumbuhan hifa. Hasil uji menunjukkan bahwa konidium yang berkecambah berkurang dengan naiknya kemasaman, suhu inkubasi, dan paparan cahaya.

Konidium G. sordidus dapat berkecambah kurang dari 24 jam. Rata-rata perkecambahan konidium G. sordidus kurang dari $30 \%$ meskipun telah diinkubasi lebih dari 76 jam. Hifa konidium yang berkecambah selalu menembus permukaan sel daun dan tidak ditemukan hifa yang masuk melalui stoma meskipun beberapa hifa terlihat tumbuh di atas permukaan lubang stoma. Infeksi $E$. necator penyebab gejala embun tepung pada anggur umumnya melibatkan proses mekanik dari hifa, tetapi beberapa spesies dari Erysiphe dapat mensintesis enzim yang menyebabkan depolimerasi kutikula dan dinding sel tanaman inang (Schnee et al. 2013).

Setiap cendawan mempunyai kepekaan yang tidak sama terhadap kuantitas dan kualitas cahaya, bahkan tiap fase dari tiap cendawan mempunyai kepekaan yang berbeda terhadap cahaya. Tanaman yang tidak langsung terpapar cahaya merupakan kondisi ideal bagi G. sordidus untuk berkembang. Shomari dan Kennedy (1999) mendapatkan koloni embun tepung yang disebabkan oleh Oidium anacardii yang ada di cabang bagian dalam kanopi tanaman mete tumbuh lebih cepat dibandingkan dengan yang ada di bagian luar.

Cahaya menghambat perkecambahan konidium, sehingga mengurangi peluang terjadinya infeksi, mungkin juga karena terjadi kenaikan suhu mikro di sekitar permukaan daun yang terkena cahaya matahari. Oleh karena itu, tanaman yang segera diletakkan di lapangan setelah diinokulasi tidak ada yang terinfeksi. Inkubasi pada tempat yang terhindar dari cahaya selama 48 jam atau lebih meningkatkan peluang $G$. sordidus berkecambah dan menginfeksi daun. Dalam batas tertentu, hifa G. sordidus yang telah berada di dalam jaringan tanaman relatif lebih tahan terhadap pengaruh cahaya maupun 
kenaikan suhu, sehingga dapat berkembang membentuk koloni baru, yang selanjutnya akan menjadi sumber inokulum. Suhu lingkungan juga mempengaruhi daya sporulasi cendawan penyebab embun tepung. Jumlah konidium Oidium sp. asal tanaman Euphorbia pulcherima yang terperangkap berkurang seiring dengan naiknya suhu di rumah kaca, dan koloni yang ada tidak bertambah apabila suhu rata-rata mingguan melebihi $30^{\circ} \mathrm{C}$ (Byrne et al. 2000). Peduto et al. (2013) mendapatkan konidium E. necator membutuhkan suhu optimum untuk berkecambah $33.5{ }^{\circ} \mathrm{C}$, dan konidiumnya sudah berkecambah kurang dari 24 jam, perkecambahan akan terjadi kurang dari 4 jam apabila diinkubasi pada suhu $40.5{ }^{\circ} \mathrm{C}$. Inkubasi pada suhu $36^{\circ} \mathrm{C}$ atau lebih tinggi selama 12 jam akan menyebabkan koloni E. necator tidak mampu bersporulasi meskipun lingkungan kembali normal (Peduto et al. 2013). Cendawan E. necator apabila diinkubasi pada suhu $8{ }^{\circ} \mathrm{C}$ akan menghasilkan apresorium yang lebih sedikit tetapi percabangan hifa yang lebih banyak dibandingkan dengan yang diinkubasi pada $2{ }^{\circ} \mathrm{C}$ (Moyer et al. 2010). Suhu merupakan faktor lingkungan yang penting untuk ketahanan tanaman, $E$ trifolii mampu menginfeksi kacang kapri ( $P$. sativum) yang mengandung gen tahan $E r 3$, ditandai adanya koloni embun tepung pada hari ke-9 apabila tanaman diinkubasi pada suhu $25^{\circ} \mathrm{C}$, tetapi tidak apabila diinkubasi pada $20{ }^{\circ} \mathrm{C}$ (Fondevilla et al. 2013). Shi dan Mmbaga (2006) menyarankan melakukan pemangkasan di awal musim semi untuk mengurangi serangan embun tepung pada Lagerstroemiae indica yang disebabkan oleh E. australiana, karena cendawan yang tidak membentuk stadia sempurna dapat bertahan berupa miselia pada pucuk $L$. indica yang dorman selama musim dingin. Aplikasi fungisida pada waktu yang tepat, pada bagian tanaman yang peka dan periode aplikasi yang tepat dilaporkan efektif menekan embun tepung (Oidium sp.) pada rambutan (Rajapakse et al. 2006).

Cendawan $G$. sordidus yang bersifat sebagai parasit sejati, dan kisaran inang yang terbatas, serta tanaman ki-urat yang mampu tumbuh pada kisaran lingkungan yang kering, memungkinkan untuk melakukan pengendalian embun tepung secara kultur teknis. Serangan G. sordidus dapat ditekan dengan dengan menanam ki-urat di tempat yang tidak terlalu teduh, disertai dengan tindakan pengendalian secara mekanis dengan mengambil dan me-musnahkan bagian tanaman terserang.

\section{DAFTAR PUSTAKA}

Bahadur A, Singh UP, Singh DP, Sarma BK, Singh KP, Singh A, Aust HJ. 2008. Control Erysiphe pisi causing powdery mildew of pea (Pisum sativum) by cashewnut (Anacardium occidentale) shell extract. Mycobiology. 36(1):6065. DOI: http://dx.doi.org/10.4489/ MYCO.2008.36.1.060.

Bardin M, Suliman ME, Sage-Palloix AM, Mohamed YF, Nicot PC. 2007. Inoculum production and long-term conservation methods for cucurbits and tomato powdery mildews. Myc Res. 111:740747. DOI: http://dx.doi.org/ 10.1016/j. mycres.2007.03.15.

Braun U. 1987. A monograph of the Erysiphales (powdery mildews). Berlin (DE): Nova Hedwigia.

Byrne JM, Hausbeck MK, Shaw BD. 2000. Factor affecting concentrations of air borne conidia of Oidium sp. among Poinsettias in a green house. Plant Dis. 84:10891095. DOI: http://dx.doi.org/10.1094/ PDIS.2000.84.10.1089.

Crous PW, Verkley GJM, Groennewald JZ, Samson RA. 2009. Fungal Biodiversity. Utrecht (NL): CBS-Knaw Fungal Biodiverisity Centre.

Dallagnol LJ, de Castro FR, Garcia EN, Camargo LEA. 2012. First report of powdery mildew caused by Golovinomycs sp. on Plantago australis in Brazil. Plant Dis. 97(3):421. DOI: http://dx.doi. org/10.1094/PDIS-07-12-0660-PDN.

Delhey R, Braun U, Kiehr M. 2003. Some new records of powdery mildew from Argentina (2). Schlectendalia. 10:79-90. 
Dugan FM, Glawe DA. 2007. Powdery mildews on weeds in the Pacific Northwest: a miscellany of new reacords. Pacific Northwest Fungi. 2(1):1-7. DOI: 10.2509/pnwf.002.001.

Farr DF, Bills GF, Chamuris GP, Rossman AY. 1989. Fungi on Plants and Plant Products in the United States. St. Paul Minnesota (US): APS Pr.

Fondevilla S, Chattopadhyay C, Khare N, Rubiales D. 2013. Erysiphe trifolii is able to overcome erl and Er3, but not er2, in resistance genes in pea. Eur J Plant Pathol. 136:557-563. DOI: http://dx.doi. org/10.1007/s10658-013-0187-6.

Kobayashi T, Oniki M, Matsumoto K, Sitepu D, Manohara D, Tombe M, Djiwanti SR, Nurawan A, Rachmat A, Wahyuno D, Nazarudin SB, Mustika I, Shiomi T, Tsuchiya K, Katumoto K. 1993. Diagnostic Manual for Industrial Crop Diseases in Indonesia. Jakarta (ID): JICA-RISCM.

Kobeasy MI, Abdel-Fatah OM, ElSalam SMA, Mohamed ZEM. 2011. Biochemical studies on Plantago major L. and Cyamopsis tetragonoloba L. Int J Biodivers Conserv. 3(3):83-91.

Kosobrukhov A, Knyazeva I, Mudrik V. 2004. Plantago major plants response to increase content of lead of leaf in soil: growth and photosynthesis. Plant Growth Regulation. 42:145-151. DOI: http://dx.doi.org/10.1023/ B:GROW.0000017490.59607.6b.

Liberato JR, Barreto RW, Shivas RG. 2005. Leaf-clearing and staining technique for the observation of conidiophores in the Phyllactinioides (Erysiphaeceaei). Aus Plant Pathol. 34:401-404. DOI: http:// dx.doi.org/10.1071/AP05027.

Moyer MM, Gadoury DM, Cadle-Davidson L, Dry IB, Magarey PA, Wilcox WF, Seem RC. 2010. Effect of acute lowtemperature events on development of Erysiphe necator and susceptibility of Vitis vinifera. Phytopathology. 100(11):12401249. DOI: http://dx.doi.org/10.1094/ PHYTO-01-10-0012.

Nisar M, Ghafoor A, Rashid K, Quresh AS. 2006. Screening of Pisum sativum L. germplasm against Erysiphe pisi Syd. Acta Biol Cracov Ser Bot. 48(2):33-37.

Pangemanan L. 1999. Plantago. Di dalam: Padua LS, Bunyapraphatsara N, Lemmens RHMJ, editor. Plant Resources of SouthEast Asia. Medicinal and Poisonous Plants. No 12(1). Bogor (ID): Prosea. hlm 397-403.

Peduto F, Backup P, Hand EK, Janousek CN, Gubler WD. 2013. Effect of high temperature and exposure time on Erysiphe necator growth and reproduction: revisions to the UC Davis Powdery Mildew Risk Index. Plant Dis. 97(11):1438-1447. DOI: http://dx.doi.org/10.1094/PDIS-01-130039-RE.

Rajapakse RGAS, Edirimanna ERSP, Kahwatta J. 2006. Management of powdery mildew disease of rambutan (Nephelium lappaceum) in Sri Lanka. J Agric Sci. 2(3):8-14.

Romeh AA. 2014. Phytoremediumtion of cynaophos insecticide by Plantago major $\mathrm{L}$. in water. J Environ Health Sci Eng. 12:1-8. DOI:http://dx.doi.org/10.1186/2052336X-12-38.

Ruzgas V, Petrauskas P, Liatukas Ź. 2002. Resistance of winter wheat varieties to fungal diseases Erysiphe graminis DC sp. tritici E. Marshal, Septoria tritici Rob et Desm and Stagonospora nodorum Berk. Biologija. 1:43-45.

Samuelsen AB. 2000. The traditional uses, chemical constitutents and biological activities of Plantago major L. A review. J Ethnopharmacol. 71:1-21. DOI: http://dx.doi.org/10.1016/S03788741(00)00212-9.

Schnee S, Rougeux E, Pezet R, Viret O, Gindro K. 2013. Evidence for constitutive cutinase in urgeminated conidia of Erysiphe necator Schwein. J Cytol Histol. 4(5):197. DOI:http://dx.doi.org/10.4172/21577099.1000197.

Schrandt JK. Davis RM.. 1994. Host range and influence of nutrition, temperature and $\mathrm{pH}$ on growth of Phytium violae from carrot. Plant Dis. 78:335-338. DOI: http:// dx.doi.org/10.1094/PD-78-0335. 
Shi A, Mmbaga MT. 2006. Perpetuation Shomari SH, Kennedy R. 1999. Survival of of powdery mildew infection and identification of Eysiphe australiana as the Oidium anacardii in cashew (Anacardium occidentale) in Southern Tanzania. Plant crape myrtle pathogen in mid-Tennessee. Plant Dis. 90(8):1098-1101. DOI: http:// dx.doi.org/10.1094/PD-90-1098. Pathol. 48:505-513. DOI: http://dx.doi. org/10.1046/j.1365-3059.1999.00363.x. 